УДК 159.9019.4:001.8(045)

DOI https://doi.org/10.26661/2310-4368/2020-2-12

\title{
БІОЛОГІЧНІ ЧИННИКИ СТАНОВЛЕННЯ ГОМОСЕКСУАЛЬНОСТІ ІНДИВІДА
}

\author{
Ткалич М. Г. \\ доктор психологічних наук, \\ професор кафедри психології \\ Інститут підготовки кадрів державної служби зайнятості України \\ вул. Нововокзальна, 17, Київ, Україна \\ orcid.org/0000-0003-4101-9659 \\ mtkalych@gmail.com \\ Гречаник М. I. \\ аспірантка кафедри психології \\ Інститут підготовки кадрів державної служби зайнятості Украйни \\ вул. Нововокзальна, 17, Київ, Украӥна \\ orcid.org/0000-0003-1650-3692 \\ kunjutkazp@gmail.com \\ Гречаник Є. О. \\ психолог \\ orcid.org/0000-0001-8413-8848, \\ grechanyk41@gmail.com
}

\begin{abstract}
Ключові слова: сексуальна орієнтація, гомосексуальність, індивід, статева поведінка, біологічні чинники, онтогенетичний розвиток, еволючія.
\end{abstract}

У статті представлено теоретичний аналіз та обгрунтування біологічних чинників становлення гомосексуальності індивіда. Виділено окремий вплив генетичного, онтогенетичного й етологічного факторів на процес формування сексуальної орієнтації індивіда. Здійснено аналіз гомосексуальності крізь призмуеволюційноїпсихології.Визначенофакторионтогенетичногорозвитку, які впливають на становлення гомосексуальності. Проаналізовано фактори гормонального впливу, який здійснюється протягом внутрішньоутробного розвитку, на становлення гомосексуальності, відзначено вплив тестостерону на поведінку й статеві відмінності в людини й інших тварин. Особливу увагу приділено статевій диференціації мозку під час внутрішньоутробного розвитку. Також розглядається зв'язок стресу матерів і пренатального періоду зі становленням гомосексуальності. Здійснено аналіз основних еволюційних факторів, які впливають на формування гомосексуальності: адаптивність, родинний відбір, нейтральні ознаки, репродуктивний успіх. Важливу увагу приділено питанню дихотомізації статевої поведінки на розбірливу й нерозбірливу в контексті еволюції. Здійснено огляд етологічних чинників розвитку приматів, встановлено зв'язок периферізації, групового способу виживання серед приматів і становлення гомосексуальності, яке може бути спрямоване не лише на задоволення репродуктивних потреб, але й на розв'язання внутрішньогрупових конфліктів, на підвищення соціального статусу в групі, підвищення шансів на виживання, обмін ресурсами, й у цьому контексті гомосексуальність слід розглядати як механізм об'єднання в спільноти проти небезпеки. Здійснено теоретико-методологічний аналіз впливу біологічних чинників на становлення гомосексуальності в процесі еволюції: визначено, що існує значний біологічний внесок у розвиток гендерної ідентичності й сексуальної орієнтації людини. 


\title{
BIOLOGICAL FACTORS CONTRIBUTING TO THE DEVELOPMENT OF HOMOSEXUALITY
}

\author{
Tkalych M. H. \\ Doctor of Psychological Sciences, \\ Professor at the Department of Psychology \\ Ukrainian State Employment Service Training Institute \\ Novovokzalna str., 17, Kyiv, Ukraine \\ orcid.org/0000-0003-4101-9659 \\ mtkalych@gmail.com \\ Hrechanyk M. I. \\ Postgraduate Student at the Department of Psychology \\ Ukrainian State Employment Service Training Institute \\ Novovokzalna str., 17, Kyiv, Ukraine \\ orcid.org/0000-0003-1650-3692 \\ kunjutkazp@gmail.com
}

Hrechanyk E. O.

Psychologist

orcid.org/0000-0001-8413-8848, grechanyk41@gmail.com

Key words: sexual orientation, homosexuality, individual, sexual behavior, biological factors, ontogenetic development, evolution.
The article presents a theoretical analysis and justification of biological factors of individual homosexuality. The separate influence of genetic, ontogenetic and ethological factors on the process of formation of sexual orientation of an individual has been highlighted. The analysis of homosexuality through the prism of evolutionary psychology has been carried out. The factors of ontogenetic development that influence the formation of homosexuality have been determined. Also we have analyzed the factors of hormonal influence, which is carried out during fetal development on the formation of homosexuality; the influence of testosterone on the behavior and sex differences in humans and other animals. Particular attention was paid to sexual differentiation of the brain during fetal development. The relationship between maternal stress and the prenatal period and the development of homosexuality has been also considered. The main evolutionary factors influencing the formation of homosexuality are the following: adaptability, family selection, neutral traits, reproductive success. Important attention was paid to the issue of dichotomizing sexual behavior into intelligible and illegible in the context of evolution. The ethological factors of primate development have been reviewed, the connection between peripheralization, group way of survival among primates and the formation of homosexuality was established, which can be aimed not only at satisfying reproductive needs, but also at resolving intragroup conflicts and increasing social status in the group, the chances of survival, exchanging resources and in this context, homosexuality should be seen as a mechanism for uniting in a community against danger. Theoretical and methodological analysis of the influence of biological factors on the formation of homosexuality in the process of evolution was carried out: it was determined that there is a significant biological contribution to the development of gender identity and sexual orientation of an individual. 
Постановка проблеми. Нині проблема гомосексуальності особистості в Україні викликає суперечності й значні прояви ксенофобії в різних суспільних прошарках. Відмінності іншого, так звана «інакшість» людини викликають страх, відразу, розділення за принципом «свій-чужий», наслідком цього часто є намагання здійснення насильства щодо гомосексуальних людей. Гомосексуальні люди щодня зазнають дискримінації на робочих місцях, порушення власних прав і загалом почувають себе в небезпеці. Таке ставлення, на наш погляд, викликане стереотипами, міфами й забобонами, якими оповита тема гомосексуальності. Низьким лишається рівень обізнаності щодо впливу біологічних чинників становлення гомосексуальності особистості, що породжує стереотипи, упередження, транслювання помилкових суджень у суспільстві й формування негативного ставлення до представників ЛГБТКІ. Важливо також підвищувати рівень психоедукації суспільства, формувати толерантне ставлення до гомосексуальних людей. Необхідно зазначити, що використання коректної лексики, знання не лише соціально-психологічних особливостей, а й механізмів дії біологічних чинників становлення гомосексуальності допоможе психологам-практикам надавати психологічні послуги якісніше й запобігати упередженому ставленню до людини на підставі сексуальної орієнтації.

Аналіз останніх досліджень і публікацій. Оскільки проблематика дослідження має міждисциплінарний характер, насамперед треба виділити ті роботи, які загалом присвячені вивченню гомосексуальності особистості. Значний внесок у вивчення чинників, які спонукають становлення гомосексуальності, належить працям 3. Фройда, Е. Еріксона, С. Бем, І. Кона. У. Мастерса, В. Джонсона, А. Кінсі, Г. Теджфела й низці інших авторів. Серед сучасних вітчизняних дослідників варто відзначити роботи М. Ткалич, П. Горностая, М. Яромовіц, О. Кікінежді, Т. Говорун. Серед вчених, які досліджували онтогененичний аспект проблеми, можна згадати J. Weauwer, C.E. Roselli, С. Лерман. У своїх роботах вони розкривають вплив гормонів під час внутрішньоутробного розвитку на статеву диференціацію мозку, вплив серотоніну на статеві вподобання ссавців під час формування сексуальної орієнтації та гендерної ідентичності.

Важливо також виокремити роботи, метою яких $\epsilon$ вивчення впливу стресу, якого зазнавала особистість під час внутрішньоутробного розвитку. Це B. Ward, S. Ridd, O. Vynn та E. Bilansky. Серед досліджень, які викладають еволюційний і генетичний аспекти біологічних чинників гомосексуальності, можна виділити роботи О. Маркова, В. Гранта М. Лемберта, Л. Палмер, Дж.
Палмер, Р. Сапольскі. Останні дослідження за темою гомосексуальності з боку еволюції присвячені вибірковості статевої поведінки, першочерговості нерозбірливої статевої поведінки в древі еволюції, співвідношенню затрачених ресурсів і репродуктивного успіху, функції гомосексуальної поведінки - альтруїзму, родинному відбору, гомосексуальності як нейтральній ознаці, яка передається в спадок. Серед робот, які досліджували етологічний компонент гомосексуальності, важливими є дослідження F. Muscarella, який приділив увагу вивченню гомоеротичної поведінки в гомінідів, також важливе вивчення поведінки шимпанзе й феномену гомосексуальності як способу розв'язання конфлікту в групі й збереження соціального статусу, розкрите в дослідженнях B. Hare, V. Woods, що відбиває соціо-біологічний аспект вивчення проблеми.

Метою дослідження $\epsilon$ теоретичний аналіз та обгрунтування біологічних чинників, які лежать в основі становлення гомосексуальності індивіда.

Серед основних завдань дослідження виокремимо такі:

1) обгрунтування ролі еволюційних факторів у процесі становлення гомосексуальності індивіда;

2) аналіз і систематизацію основних біологічних чинників становлення гомосексуальності;

3) визначення особливостей онтогенетичного розвитку, які є ключовими для становлення гомосексуальності.

Виклад основного матеріалу дослідження. Людина розумна належить до виду, якому притаманний статевий тип розмноження, людина має ідентифікувати особу протилежної статі й ця особа має привертати до себе увагу (з метою розмноження) [11, с. 31]. На перший погляд, сексуальна орієнтація не має містити інших варіантів, але дослідження поведінкової генетики свідчать про 95 \% людей, які мають гетеросексуальну орієнтацію, і як мінімум половина варіантів орієнтації має генетичну зумовленість.

У роботах I.C. Кона біомедичні дослідження гомосексуальності групувалися за 4 розділами:

1) порівняльна й еволюційна біологія та соціобіологія;

2) генетика й молекулярна біологія;

3) ендокринологія та нейроендокринологія;

3) нейроанатомія та нейрофізіологія [4].

Додатковими джерелами даних слугує клініка зміни статі й сексуальної орієнтації.

У дослідженні аналіз феномену гомосексуальності передбачає вивчення таких аспектів: онтогенетичного, генетичного й аспекту впливу еволюційних факторів.

Онтогенетичний аспект представлений у дослідженнях J. Weauwer, C.E. Roselli, C. Лерман і в цілому визначає, що всі особини починають 
свій розвиток з однакових вихідних даних, однакової побудови тіла, включно 3 репродуктивною системою. Вважається, що до певного часу ембріональна гонада зародка є недефиренційованою, тобто вона може переростати в чоловічі чи жіночі статеві органи. Чоловічі статеві органи розвиваються $з$ ембріональної гонади дією експресії гену, що визначає стать, SRY на Y-хромосомі. Експресія гену - це процес, під час якого інформація, яку містить ген, використовується для синтезу функціонального продукту, білків чи рибонуклеїнової кислоти (інакше кажучи, це процес запуску розвитку) [5]. Аналогічно, в зародку є 2 системи проток, пов'язаних 3 урогенітальною диференціацією, Вольфівська й Мюллерова протоки, які здатні переростати в чоловічі й жіночі трубчасті репродуктивні шляхи відповідно. Як тільки відбувається диференціація за розвитком чоловічих статевих органів, починається синтез 2 гормонів - тестостерону й антимюллерівого гормону (далі - АМГ). У щурів це відбувається приблизно на 16-17 день гестації, тоді як у людей це відбувається приблизно на 7-8 тижнях гестації, а на 5 тижні гестації починається статева диференціація ембріональної гонади [17].

Тестостерон і дигідротестостерон (похідна сполука від тестостерону), індукують диференціацію інших органів у репродуктивній системі самців, тоді як АМГ спричиняє дегенерацію мюллерових проток (два канали, 3 яких у жіночих ембріонів наприкінці третього місяця починають утворюватися маткові труби). Жіночий репродуктивний тракт в ембріона розвивається за відсутності андрогенів і згодом дозріває під впливом гормонів, що виробляються яєчником, зокрема естрадіолу. Подібні процеси відбуваються під час внтурішньоутробного розвитку й статевої диференціації мозку ссавців. Типовий для жінок (фемінізація) та чоловіків (маскулінізація) розвиток відбувається під впливом дії тестостерону: для жінок - за умовної його відсутності [11]. Маскулінізація викликає зміни, що індукуються дією стероїдних гормонів. У щурів утворення естрадіолу в мозку шляхом ароматизації циркулюючого тестостерону є найважливішим механізмом маскулінізації мозку; відповідно, тестостерон, ймовірно, діє безпосередньо без перетворення в естрадіол, впливаючи на гендерну ідентичність людини й сексуальну орієнтацію. Періоди, коли тестостерон викликає статеву диференціацію мозку в різних видів, відповідають періодам, коли тестостерон найбільше підвищений у чоловіків у порівнянні 3 жінками. У гризунів та інших тварин це відбувається протягом перших 5 днів після народження, в людей підвищення тестостерону відбувається між 2 та 6 місяцями вагітності, після пологів від 1 до 3 місяців. Слід зауважити, що рівень тестосте- рону в чоловіків вищий, ніж у жінок, приблизно до П'ятого тижня (з моменту зачаття та утворення зиготи), чоловіки й жінки мають однакові фенотипічні ознаки [10]. Лише після диференціації статевих залоз і продукування ними відповідних гормонів ми можемо спостерігати розподіл ембріонів на чоловічі й жіночі. У цьому моменті вагомими $є$ аспекти диференціації репродуктивної системи, й особливо диференціація мозку.

У дослідженнях C.E. Roselly [17], Д. Свааба [9] зазначається, що первинною моделлю виступає жіночий мозок, і тут є парадоксальним моментом те, що жіночий гормон естрадіол маскулінізує мозок. Пренатальна схема розвитку мозку визначає багато аспектів поведінки чоловіків і жінок включно 3 сексуальною орієнтацією. Правдивішим $є$ наслідування не специфічних генів, які відповідають за гомосексуальність, а, скоріше, генів, які роблять людину менш стійкою до впливу в період пренатального розвитку мозку.

Існують дослідження, які доводять вплив гормонів на статеву диференціацію мозку під час внутрішньоутробного розвитку. Зокрема, це дослідження, які стверджують про вплив материнського стресу на внутрішньоутробний розвиток мозку. O.B. Ward et al. викликали стрес у вагітних пацюків, внаслідок чого частина ендорфіну проникала крізь плаценту й досягала відповідних структур мозку в гипоталамусі зародку, ендорфіни як материнські гормони стресу блокують синтез і вивільнення тестостерону. Дитинчата, народжені в цьому випадку, показували варіант поведінки, яка може ідентифікуватись як гомосексуальна [18]. Дані, що свідчать про подібну модель сексуальної орієнтації людини, були також зібрані E.L. Peckham et al: вчені обстежили 283 матерів чоловіків із гомо- й гетеросексуальною орієнтацією. Жінок методом інтерв'ю обстежували щодо соматичних захворювань, стресів, які вони переживали протягом вагітності. 3'ясувалося, що матері, які мали хоча б один серйозний епізод протягом другого триместру вагітності, мали вищу вірогідність народження сина 3 гомосексуальною орієнтацією [20]. Детальніше дослідження L. Willerman et al не виявило високої кореляції допологового стресу й гомосексуальної орієнтації в дитини, однак за результатами цього дослідження в хлопців, чиї матері мали високий стрес під час вагітності, частіше спостерігалась поведінка, притаманна дівчатам [21].

Важливими $є$ особливості гормонального впливу в період внутрішньоутробного розвитку для формування сексуальної орієнтації жінок. Відомо, що наприкінці 50-х - початку 60-х років багато жінок вживали синтетичний естроген, діетілстілбестрол (далі - DES), для попередження викиднів. DES створює маскулінізуючий вплив 
на кшталт впливу тестостерону. А. Марков цитує дослідження М. Ehrnhardt et al, в якому вчені виявили, що 3 тридцяти обстежених ними дорослих жінок, чиї матері під час вагітності приймали DES, сім мали гомосексуальну чи бісексуальну орієнтацію. Якщо порівняти тридцять жінок, які не мали внутрішньоуробного впливу DES, у жодної не було виявлено гомо- чи бісексуальності. Також у жінок, які зазнавали під час внутрішньоутробного розвитку дію високого рівня тестостерону, через синдром вродженої гіперплазії набагато частіше спостерігається бісексуальна або гомосексуальна орієнтація [8].

Важливими у визначенні біологічного підгрунтя гомосексуальності також є відмінності в будові мозку. Наприклад, передня коміссура (comissura anterior) - пучок нервових волокон, який забезпечує зв'язок між обома півкулями, в середньому більше у жінок, ніж у гетеросексуальних чоловіків. У гомосексуальних чоловіків вона не відрізняється за розмірами й навіть перевершує таку в жінок (Alien \& Gorski, 1992). Структура, яка перебуває в передньому гіпоталамусі, відома як інтерстіциальне ядро-3, зазвичай удвічі більше в гетеросексуальних чоловіків, ніж у жінок. У гомосексуальних чоловіків це утворення має приблизно такий же об'єм, як і в жінок [10]. В інших частинах гіпоталамуса (щодо яких відомо, що вони відрізняються в осіб різної статі) гомосексуальні чоловіки схожі з гетеросексуальними чоловіками й несхожі з гетеросексуальними жінками. Це означає, що сексуальна орієнтація не є суворо дихотомічною, а має певні ступені чи градації.

Отже, можна стверджувати, що гомосексуальна орієнтація є продуктом онтогенетичного континууму, подібно статевій анатомії та фізіології. Важливим аспектом є статева диференціація мозку, формування сексуальної орієнтації відбувається під час внутрішньоутробного розвитку: в цей період вагомим $є$ вплив гормонів, зокрема тестостерону й естрадіолу. Таким чином, гомосексуальна орієнтація, яка $є$ складною інтегративною характеристикою, базується на біологічних чинниках.

Проаналізуємо генетичний аспект формування гомосексуальності, який представлений у роботах J.M. Bailey та R.C. Pillard [22], Р. Докінза [3], Р. Сапольскі [9]. Слід зазначити, що генетичний аспект $є$ тісно переплетеним 3 еволюційним, оскільки сучасна синтетична теорія еволюції використовує генетику як метод, який доводить i розкриває еволюцію [7, с. 44]. Дослідження поведінкової генетики в області сексуальної орієнтації людини (J.M. Bailey, R.C. Pillard, 1992) свідчать, що різноманіття сексуальної орієнтації зумовлене генетично [22]. Є певною загадкою, чому інфор- мація про абсолютно неефективну з боку виживання та забезпечення репродуктивного успіху поведінку закодована в генах і передається поколінням?

Р. Сапольскі стверджує, що доречнішою в цьому контексті виглядає теза «гени впливають на те, як ми реагуємо на середовище»: це означає, що існує, по-перше, генетичне різноманіття індивідів, по-друге, це свідчить про те, що існують фактори середовища, які можуть активізувати експресію (запуск) гена [9, с. 34].

P. Докінз розглядає гомосексуальність як фенотипічний прояв генів у впливі певного середовища. «Фенотипічний «ефект» гена - поняття, що має сенс тільки в певному контексті впливів навколишнього середовища, причому довкілля містить і всі інші гени генома. «Ген ознаки А» в оточенні $\mathrm{X}$ може запросто виявитися геном ознаки В в оточенні Ү». Р. Докінз стверджує, що якби існував ген гомосексуальності, він існував би й раніше, в іншому історичному періоді активував би іншу функцію. Р. Докінз розглядає аспект гомосексуальності крізь призму «ефекту запізнювання в часі», коли фенотип, який потребує аналізу, міг і не існувати в інших умовах середовища, й це не дивлячись на те, що відповідний ген тоді вже щосили існував. Тобто, «ефект запізнювання» стосується не лише змін навколишнього середовища, які проявлялися в зміні тиску відбору, а й зміни навколишнього середовища можуть змінювати саму природу фенотипічної ознаки, яка потребує аналізу. Це означає, що, умовно, ген, який зараз відповідає за гомосексуальність, раніше міг відповідати за інші функції або йти поряд 3 важливими функціями й передаватись у спадок. Важливо відзначити феномен «відставання в часі», коли фенотипічна ознака може проявлятися, а може й не проявлятися в певному середовищі, тобто цілком можливо, що ген, який нині відповідає за гомосексуальність, в інші періоди активував інші фенотипічні ознаки. Таким чином, можна зробити висновок, що гомосексуальна орієнтація як фенотипічна ознака зумовлена генетично, але важливою є взаємодія генів із середовищем. Оскільки онтогентичний, еволюційний і генетичний аспект тісно пов'язані, варто навести приклад про вплив материнського стресу під час вагітності, який був описаний вище. Це є наочним прикладом впливу середовища й запуском для експресії відповідних генів.

Дослідження еволюиійного аспекту гомосексуальності представлено в роботах Ф. де Вааля, О. Маркова, В. Гранта, Дж. Палмера й Л. Палмер, F. Muscarella. Якщо аналізувати гомосексуальність із боку поведінки, можна побачити велику кількість тварин, які мають одностатеву поведінку, це більше ніж півтори тисячі видів тварин. 
Велика представленість у тваринному світі одностатевої сексуальної поведінки постійно розглядається як еволюційний парадокс. Існує дві думки, які пояснюють факт існування одностатевої поведінки: 1) одностатевий секс має негативний вплив на адаптивність (звідси - важливість прямих або непрямих переваг, які переважають шкоду); 2) різностатевий секс - еволюційно раніший механізм для тварин, а одностатевий - більш пізня «надбудова» [6].

Дослідження D.J. Monk et al має принципово інший погляд на ці тези [16]. Як стверджують вчені, першочерговою могла бути нерозбірлива статева поведінка, спрямована на представників обох статей свого виду й та, що не потребує вміння визначати стать партнера, а негативний вплив епізодичного одностатевого сексу на репродуктивний успіх часто був невеликим або навіть зовсім відсутнім. У такому контексті аналізу вимагає не одностатева, а різностатева сексуальна поведінка, яка потребує розвитку складних систем виокремлення представників протилежної статі й корелює з ризиком втрачених репродуктивних можливостей [16]. Дослідження пропонує докорінно переглянути усталені підходи до вивчення еволюційного розуміння гомосексуальної поведінки. Автори дослідження використовують поняття «одностатевої статевої поведінки» (same-sex sexual behaviours, SSB). Одностатева статева поведінка (далі - ОСП) трактується як поведінка, налаштована на представника своєї статі, яка через те, що спрямована на особину протилежної статі, може сприяти успішному розмноженню. Відповідно, замість «гетеросексуальності» автори говорять про «різностатеву статеву поведінку (далі - РCП)» (different sex sexual behaviours, DSB) [16 ].

У класичному еволюційному розумінні статева поведінка $є$ засобом посилення репродуктивного успіху, у зв'язку із чим широка поширеність варіантів статевої поведінки виглядає парадоксально (роботи Ч. Дарвіна, М. Хейла, Т. Моргана). Також слід зауважити, що статева поведінка тварин часто спрямована не лише на представників протилежної статі, але й на самих себе (аутостимуляція), на представників своєї статі, на представників інших видів, на мертвих особин і неживі предмети [15]. J.D. Monk et al наголошують на тому, що нерозбірлива статева поведінка має бути первинною 3 боку еволюції та еволюція статевої поведінки відбувалася в бік різностатевої поведінки незалежно на різних гілках (коли вибір точнішого партнера переважував пов' язані із цим витрати) [16]. Однак вчені поки що мають не досить даних: відомості про народження SSB у різних видів вкрай фрагментарні. Дослідники часто ігнорують випадки $\mathrm{SSB}$, які спостерігаються або не класифікують їх як статеву поведінку, а відносять до інших категорій соціальної взаємодії. У багатьох тварин статева приналежність не так просто визначається, i тому спостерігачі можуть прийняти SSB за DSB. Нарешті, в лабораторних дослідженнях статевої вибірковості тваринам рідко дають можливість вибирати між представниками своєї та протилежної статі.

Нині найрозробленішою системою уявлень про процеси еволюції є синтетична теорія еволюції (далі - СТЕ) Дж. Хакслі. Основою СТЕ $є$ динаміка генетичної структури популяції. СТЕ $€$ синтезом різних дисциплін зокрема генетики й дарвінізму, й поєднує різні компоненти для цілісного бачення процесів. Одним з основних положень синтетичної теорії еволюції є адаптивність. Еволюційна психологія завжди задається питанням, чому існує поведінка, які завдання вона виконує. Одним із ключових факторів $є$ адаптивність поведінки, тобто це фактор, що сприяє репродуктивному успіху, прямо чи опосередковано (Buss et al, 1998; Tooby \& Cosmides, 1992). Загалом, консенсус у галузі еволюційної психології полягає в тому, що гомосексуальна поведінка не має адаптивного значення, а отже, не має розвиватись (тобто передаватись далі) [6, с. 243]. F. Muscarella стверджує, що людська сексуальність помилково пояснюється принципом дихотомізації, коли гетеросексуальність розглядається як виключно репродуктивна, а гомосексуальність - нерепродуктивна [14]. Автор пропонує розглядати одностатеву сексуальну поведінку незалежно від сексуальної орієнтації та пропонує таку назву для неї: «гомоеротична поведінка». Водночас дуже часто гомоеротична поведінка розглядається як статевий контакт, за такої умови не включається мотивація поведінки. F. Muscarella стверджує, що сексуальність людини не $є$ дихотомічною. Відповідно, в ході еволюції індивіди мали б виявляти як гетероеротичну, так і гомоеротичну поведінку. Будь-яка ознака, яка закріплюється в процесі відбору, має пристосувальне значення. Припускається, що гомініди пережили період соціально-фізичної периферії, поділу статі. Автор вказує, що достеменно неможливо стверджувати, якою була поведінка гомінідів, але є можливість проаналізувати соціальну поведінку інших приматів - шимпанзе, шимпанзе-бонобо [14].

Існує припущення, що пращури ранніх гомінів жили в слабо пов'язаних групах із 50-60 особин, що містили чоловіків, жінок та їх потомство (Кемпбелл, 1985; Вілсон, 1975). Предки гомінідів жили в загрозливому й небезпечному світі, вони, ймовірно, частіше були здобиччю, ніж мисливцями й стикались із фатальною міжгруповою агресією. Контекст існування є дуже важливим саме для підліткового віку, оскільки примати-під- 
літки мають тенденцію до соціальної та фізичної периферії: цей аспект змушує їх до перебування у вразливому становищі 3 підвищеним шансом смертності й обмеженими репродуктивними можливостями [13].

Як стверджує F. Muscarella, статевозрілі гомініди підлітків і молодих дорослих повинні були стикатися 3 двома потужними селективними тисками: основним фізичним виживанням та успішним розмноженням. Ізольовані й вразливі гомініди для підлітків з обмеженим доступом до протилежної статі могли б отримати користь від здатності приєднуватися до одностатевих груп. Одностатеві партнери як підлітків-чоловіків, так і жінок-гомінідів, можливо, допомогли їм вижити, забезпечуючи доступ до їжі й захист від агресії. Крім того, соціальні альянси, сформовані й зміцнені за допомогою гомоеротичної поведінки, можуть запропонувати переваги для особливих та унікальних репродуктивних потреб кожної статі. Союзи чоловіків, можливо, допомогли їм просунутися в соціальній ієрархії чоловіків і врешті-решт отримати товаришів. Жінки, можливо, отримали вступ до середини соціальної групи, де відносна стабільність і допомога друзів-жінок збільшили б шанси виживання їхніх дітей [14]. Про це ж йдеться і в дослідженні B. Hare, V. Woods про шимпанзе-бонобо: подібна поведінка забезпечує взаємодію, яка підвищує шанси на виживання між самками-бонобо [13]. Прояви гомоеротичної поведінки могли бути ознакою приналежності, що могли зміцнювати стосунки між одностатевими гомінідами, які перебували на периферії. Таким чином, можна стверджувати, що гомоеротична поведінка може розглядатися як така, що сприяє виживанню та опосередковано впливає на репродуктивний успіх і несе в собі адаптивну функцію.

Важливим аспектом у розгляді питання гомосексуальності є також теорія родинного відбору, завданням якої $є$ пояснення парадоксальних сценаріїв поведінки тварин із боку еволюції. Термін ввів Дж.М. Сміт, розробляли теорію Дж. Холдейн, В. Гамільтон [2]. Головна ідея теорії полягає в такому: рідні особини мають певний набір загальних генів, у представників одного посліду (братів і сестер) половина генів успадкована від одного 3 батьків, половина - від іншого. Для синтетичної теорії еволюції одиницею виступає популяція важливо не виживання окремих індивідуумів, а передача генів наступному поколінню. 3 боку статистики можна сказати, що в цій ситуації особина, яка пожертвувала собою, може передати наступному поколінню більше генів, ніж та, яка залишилася живою.

Родинний відбір також пояснює гомосексуальність, котра трапляється в багатьох видів тварин, включаючи людину. Оскільки, за визначенням, гомосексуальна поведінка виключає передачу генів наступним поколінням, можна було б очікувати його зникнення ще в незапам'ятні часи. Одне із запропонованих пояснень збереження гомосексуальності було названо теорією «помічника в гнізді» [3]. Відповідно до цієї теорії, якщо особина не продовжує себе в потомстві, але ії дії сприяють виживанню родинних особин, вона зможе передати більше генів наступному поколінню. Явище родинного відбору деякою мірою спростовує уявлення про еволюцію, оскільки на перший план виступає не пристосованість індивідуума, а пристосованість генів. Така думка приводить до концепції «егоїстичного гена». Суть цієї концепції в тому, як зазначає Р. Докінз, що для еволюції має значення передача генів наступним поколінням і виживають ті, чия поведінка забезпечує перевагу генам, хоча для самого індивідуума така поведінка може бути дуже шкідливою [3].

Існує твердження, що сексуальна поведінка людей була спрямована на репродуктивний успіх. Р. Дайамонд стверджував, що в жодного виду, крім людини, мета копуляції не настільки пов'язана із зачаттям [6, с. 78]. Виявилося, що високоорганізована статева поведінка сприяла міцним зв'язкам: у період вагітності наявність пов'язаної батьківської пари збільшувала ймовірність виживання потомства й успішне розповсюдження власних генів батьків. Оскільки складна гетеросексуальна поведінка врешті-решт привела до репродуктивного успіху, вона виявилась адаптивною.

Ф. де Вааль стверджує, що в ході еволюції людини складна високоорганізована поведінка між представниками чоловічої та жіночої статі може збільшити репродуктивний успіх для обох, а гомосексуальна поведінка $є$ результатом надбудови вже над наявною гетеросексуальною поведінкою [1]. Отже, враховуючи проаналізовані біологічні аспекти формування гомосексуальності, зазначимо, що статева поведінка людини є складним, високорозвиненим комплексом у порівнянні зі статевою поведінкою інших тварин.

Висновки та перспективи подальших досліджень. Теоретичний аналіз проблеми дозволив визначити, що серед біологічних чинників важливими $є$ онтогенетичний, генетичний та еволюційний аспекти формування гомосексуальної орієнтації.

Характеристика онтогенетичного аспекту містить етап внутрішньоутробного розвитку, під час якого відбувається становлення сексуальної оріснтації та гендерної ідентичності, коли в процесі розвитку зародку відбувається статева диференціація мозку. Під час внутрішньоутробного розвитку важливий вплив гормонів, зокрема естрадіолу й тестостерону. Збій у гормональній регуляторній функції може чинити 
вплив на статеву диференціацію мозку індивіда й приводити до становлення гомосексуальної орієнтації. Важливий також вплив материнського стресу на формування сексуальної орієнтації: сильний і тривалий стрес викликає викид гормонів, гормони своєю чергою впливають на формування мозку.

Генетичний аспект тісно пов'язаний із онтогенетичним та еволюційним аспектами, але важливо виділити, що гомосексуальність є фенотипічною ознакою, яка є генетично зумовленою характеристикою. Гомосексуальність як фенотипічна ознака має підвищувати адаптивну поведінку й приводити до репродуктивного успіху, щоб передати свої гени. Згідно 3 останніми дослідженнями, гомосексуальність слід ідентифікувати як нерозбірливу статеву поведінку, яка не вимагає особливих ресурсів, на відміну від розбірливої статевої поведінки й, відповідно, гомосексуальність виникла раніше, тож існує новий погляд на дихотомізацію статевої поведінки. Серед інших важливих чинників слід виділити гомосексуальність як нейтральну ознаку, яка передається та не несе за собою суто позитивних або негативних наслідків. 3 боку еволюції та генетики, гомосексуальність, на перший погляд, є парадоксом. Слід сказати, що не існує окремо виділеного гену, який відповідав би лише за гомосексуальність, оскільки сексуальна орієнтація та гендерна ідентичність є складними інтегративними характеристиками Але вчені пояснюють збереження інформації про гомосексуальність такими принципами: «егоїстичність генів», коли насправді природа керується не інтересами одного індивіда, а інтересами попу- ляції. Також важливо відзначити феномен «відставання в часі», коли фенотипічна ознака може проявлятися, а може й не проявлятися в певному середовищі, тобто цілком можливо, що ген, який нині відповідає за гомосексуальність, в інші періоди активував інші фенотипічні ознаки.

Еволюційний аспект розглядає гомосексуальність із боку принципів еволюції. Також важливо відзначити важливість гомосексуальності 3 боку теорії родинного відбору, згідно 3 якою, якщо особина або індивід не продовжує себе в потомстві, але іiї діï сприяють виживанню родинних особин, вона зможе передати більше генів наступному поколінню. Якщо аналізувати гомосексуальність iз боку адаптивної поведінки, слід виокремити такі твердження: гомосексуальність є одним із видів статевої поведінки, яка поширена в півтори тисячі видів тварин і може бути спрямована не лише на задоволення репродуктивних потреб, але й на розв'язання внутрішньогрупових конфліктів (як у випадку з шимпанзе-бонобо), на підвищення соціального статусу в групі, шансів на виживання, обмін ресурсами, виживання на периферії підлітків приматів, тобто гомосексуальність слід розглядати як механізм об'єднання в спільноти проти небезпеки. Феномен гомосексуальності згідно 3 теорією родинного відбору розглядається як «функція помічника в гнізді», коли особина / індивід передає не свої гени, а допомагає передати гени рідним або особинам своєї групи. Перспективи подальших досліджень автори вбачають у вивченні соціобіологічних чинників і пояснені формування гомосексуальності, виокремленні психологічних складових частин гомосексуальної ідентичності людини та їх емпіричному обгрунтуванні.

\section{ЛIТЕРАТУРА}

1. Вааль де Ф. Истоки морали: в поисках человеческого у приматов. Москва : Альпина Паблишер, 2018. $376 \mathrm{c}$.

2. Грант В. Эволюционный процесс. Критический обзор эволюционной теории. Москва : Мир. 1991. 488 c.

3. Докінз Р. Егоїстичний ген. Харків : Клуб сімейного дозвілля, 2017. 544 с.

4. Кон И.С. Гены, гормоны и мозг. Лунный свет на заре. Лики и маски однополой любви. Москва : АСТ. 1998. C. 51-74.

5. Лерман С. Х, Ү... что дальше? В мире науки. 2007. № 9. С. 18-19.

6. Марков А.В. Рождение сложности. Эволюционная биология сегодня. Москва : Corpus, Астрель, 2010. $527 \mathrm{c}$.

7. Марков А.В. Эволюция человека. Москва : Corpus, Астрель, 2011. 436 с.

8. Марков А.В. Предложен новый взгляд на эволюцию однополого секса. 02.12.2019. Элементы : веб-сайт. URL: https://elementy.ru/novosti_nauki/433574/Predlozhen_novyy_vzglyad_na_evolyutsiyu_ odnopologo_seksa.

9. Сапольски Р. Кто мы такие? Гены, наше тело, общество. Москва : Альпина нон-фикшн, 2018.290 с.

10. Свааб Д. Ми - це наш мозок. Харків : Клуб сімейного дозвілля, 2016. 530 с.

11. Палмер Дж., Палмер Л. Эволюционная психология. Секреты поведения Ноmo sapiens. 2-е изд. Санкт-Петербург : Прайм-Еврознак, 2003. 384 c. URL: https:/www.litmir.me/br/?b=227681.

12. Diamond M. Homosexuality and bisexuality in different populations. Archives of Sexual Behavior. 1993. No. 22 (4). P. 291-310. 
13. Hare B., Woods V. Being Gay Is Natural: Just Ask Bonobos (Op-Ed). March 28 2014. URL: https://www.livescience.com/44464-bonobo-homosexuality-natural.html.

14. Muscarella F. Evolution of homoerotic behavior in humans. Homosexuality Journal. 2000. Vol. 40 (1). P. 51-77.

15. Smith J.M. Group Selection and Kin Selection. Nature. 1964. No. 201 (4924). P. 1145-1147.

16. Monk J.D. Giglio E., Kamath A. et al. An alternative hypothesis for the evolution of same-sex sexual behaviour in animals. Nature Ecology \& Evolution. 2019. V. 3. P. 1622-1631.

17. Roselli C.E. Neurobiology of gender identity and sexyal orientation. Journal of Neuroendocrinology. 2018 Jul. No. 30 (7). e12562.

18. Ward O.B., Ward I.L., Denning J.H. et al. Postparturitional Testosterone Surge in Male Offspring of Rats Stressed and/or Fed Ethanol during Late Pregnancy. Hormones and Behavior 2002. No. 41. P. 229-235.

19. Weaver J. Is Homosexuality Based on a Brain Chemical? March 25 2011. URL: https://www.livescience.com/ 13408-brain-chemical-serotonin-sexual-orientation.html.

20. Peckham E.L., Ashley W., Ames M., Burke. D. Sexual orientation of human offspring may be altered by severe maternal stress during pregnancy. The Journal of Sex Research. 1988. Vol. 25. P. 152-157.

21. Willerman L., Bailey J.M., Parks C.W. (1991) A test of the maternal stress theory of human male homosexuality. Archives of Sexual Behavior. 1991. No. 20 (3 June). P. 277-293.

22. Bailey J.M., Pillard R.C.A. Genetic Study of Male Sexual Orientation. Archives of General Psychiatry 1992. No. 48 (12). P. 1089-1096.

23. Fisher-Sewall R.A. The Founders of Evolutionary Genetics. Part of the Boston Studies in the Philosophy of Science book series. 1992. (BSPS, vol. 142). P. 201-229.

\section{REFERENCES}

1. Vaal' de F. Istoki morali: $\mathrm{v}$ poiskah chelovecheskogo u primatov [The origins of morality: in search of the human in primates]. M.: Al'pina Pablisher, 2018. 376 s.

2. Grant V. Jevoljucionnyj process. Kriticheskij obzor jevoljucionnoj teorii [Evolutionary process. A critical review of evolutionary theory]. M.: Mir. 1991. $488 \mathrm{~s}$.

3. Dokinz R. Egoi'stychnyj gen [The Selfish Gene]. H.: Klub simejnogo dozvillja, 2017. 544 s.

4. Kon I.S. Geny, gormony i mozg [Genes, hormones and the brain]. Lunnyj svet na zare. Liki i maski odnopoloj ljubvi. M.: AST. 1998. S. 51-74.

5. Lerman S. H, Y... chto dal'she? [ H, Y... What next?] V mire nauki. 2007. № 9.

6. Markov A.V. Rozhdenie slozhnosti. Jevoljucionnaja biologija segodnja [The birth of complexity. Evolutionary biology today]. M.: Corpus, Astrel', 2010. $527 \mathrm{~s}$.

7. Markov A.V. Jevoljucija cheloveka. [Human evolution]. M.: Corpus, Astrel', 2011. 436 s.

8. Markov A. Predlozhen novyj vzgljad na jevoljuciju odnopologo seksa [A new look at the evolution of same-sex sex is offered] 02.12.2019 URL: https://shhshhshh.elementy.ru

9. Sapol'ski R. Kto my takie? Geny, nashe telo, obshhestvo [Who are we? Genes, our body, society]. M.: Al'pina non-fikshn, 2018. $290 \mathrm{~s}$.

10. Svaab D. My - ce nash mozok [We are our brain]. H.: Klub simejnogo dozvillja, 2016. $530 \mathrm{~s}$.

11. Palmer Dzh., Palmer L. Jevoljucionnaja psihologija. Sekrety povedenija Homo sapiens. [Evolutionary psychology. Secrets of Homo sapience behavior]. URL: https://www.litmir.me/.

12. Diamond M. (1993) Homosexuality and bisexuality in different populations. Archives of Sexual Behavior, 22(4), 291-310.

13. Hare, B., Woods, V. (2014) Being Gay Is Natural: Just Ask Bonobos (Op-Ed) March 28. URL: https://www.livescience.com/44464-bonobo-homosexuality-natural.html

14. Muscarella, F. (2000) Evolution of homoerotic behavior in humans. Homosexuality Journal. Vol. 40 (1).

15. Smith, J.M. (1964) Group Selection and Kin Selection. Nature. 201 (4924): 1145-1147.

16. Monk, J.D. Giglio, E., Kamath, A. et al. (2019) An alternative hypothesis for the evolution of same-sex sexual behaviour in animals. Nature Ecology \& Evolution.V. 3. P. 1622-1631.

17. Roselli, C.E. (2018) Neurobiology of gender identity and sexyal orientation. Journal of Neuroendocrinology. Jul. 30 (7).

18. Ward, O.B., Ward, I.L. Denning, J.H. et al. (2002) Postparturitional Testosterone Surge in Male Offspring of Rats Stressed and/or Fed Ethanol during Late Pregnancy. Hormones and Behavior 41. P. 229-235.

19. WeaverJ.(2011)IsHomosexualityBasedonaBrainChemical?March25,URL:https://www.livescience.com/ 13408-brain-chemical-serotonin-sexual-orientation.html.

20. Peckham E.L., Ashley W., Ames M., Burke. D. (1988) Sexual orientation of human offspring may be altered by severe maternal stress during pregnancy. The Journal of Sex Research. Vol. 25. 
21. Willerman, L., Bailey, J.M., Parks, C.W. (1991) A test of the maternal stress theory of human male homosexuality. Archives of Sexual Behavior 20 (3 June) : 277-293.

22. Bailey, J.M., Pillard. R.C. A (1992) Genetic Study of Male Sexual Orientation. Archives of General Psychiatry 48(12): 1089-96.

23. Fisher-Sewall R.A. (1992) The Founders of Evolutionary Genetics. Part of the Boston Studies in the Philosophy of Science book series (BSPS, vol. 142) P. 201-229. 